Danka Radulović

УДК: 343.3:159.97

University of Belgrade

Преїледни рад

Faculty of Special Education and Rehabilitation

Примљен: 1. 12. 2012.

\title{
THE CORE PROBLEM OF CRIME IN SOCIETY: PSYCHOPATH OFFENDERS ${ }^{1}$
}

This article provides an argument for the thesis that solving the problem of psychopathic crime is essential to reducing crime, in general. The author argues that psychopathy is primarily psychological (not psychiatric) phenomenon that has important implications for criminology. Based on the results of empirical researches, all the relevant indicators of the contribution of psychopathy to crime were analyzed such as: the volume and types of crimes, offenses of violence, juvenile delinquency and recidivism. It was found that the most serious crimes, early delinquency, criminal career length, the frequency of the crimes, including the dark figure of crime and recidivism, are intrinsically linked to psychopathy. Psychopaths are involved in all forms of crime, especially the crime of violence. Their violence is instrumental and predatory, not psychopathological as the mentally ill individuals is; particularly dangerous are sexual psychopaths. Psychopaths are untreatable and poorly in aversive learning, but because of the masks of non criminality and socialization they are difficult to identify. They have a constellation of malignant properties (such as high aggressiveness and amorality) that are, among others, influenced by sociocultural factors. We need strategic approaches in the area of state response and prevention of crime, that will ensure reducing psychopathic crime, but also the creation of the social context in which expression of psychopathic traits and predatory lifestyle is unprofitable and unsustainable.

Key words: crime, psychopathy, offenders, social predators, sociopsychology, criminology.

\section{Introduction}

Acknowledging the importance of psychopathy on society and criminal law system represents one of the biggest changes in the scientific approach to psychopathy in the past several decades (Cleckey,1976, Hare, 1993, Blackburn, 1998, Momirović, Popović, 2002, Radulović, 2006a). This was a result of numerous empirical research which revealed that a category of psychopaths offenders, specific in terms of psychology, neurophysiology and criminology, are primary psycho47011.

${ }^{1}$ The article is a part of the Projects of Ministry of science of Republic of Serbia No. 47008 and 
logical phenomena (Hare,1996, Radulovic,2006a). Psychopaths could no longer be viewed as just one of the psychiatric categories of crime, as earlier. Simply because unlike other types, their antisocial and deviant behaviour is not part of psychopathology process. It is part of their social predators way of life and it represents an important generator of crime in general and crime of violence in particular. Psychopathy tops the list of risk factors of future crimes and must be considered not only a central part of the problem of any punitive strategy of state, but also a strategically important issue in the field of prevention (Radulovic,2006a). Some authors even treat criminology as applied discipline of psychology, studying psychology of criminal psychopaths (Momirovic,Popovic,2002). Others, as Hare (1996) gave empirical arguments that psychopathy is psychological construct whose time has come.

\section{Who are psychopathic offenders?}

The notion psychopathy was introduced by Koch ("psychopathic inferiority”) and Kraepelin ("psychopathic personalities") in the nineteenth century, instead of earlier Prichard's term "moral insanity". It was used as a label for defects in ability to restrain the gratification of immediate egotistical desires, without sings of insane or hallucination and completely without any disorder or defect of intellect, and reasoning faculties. It refer as hard temper, shallow affection and lack of feelings, bad habits and moral dispositions, behaviour impulsiveness (Radulović, 2006a).

At the beginning of twentieth century instead of psychopathy, the term socipathy has been used very often, but more recently this term has fallen out to favour; nevertheless it was present in the first American classification DSM-I (APA,1952) as „sociopathic personality antisocial reaction “ (with alcoholism and drug dependence, sexual devitions and antisocial behavior as its subset). Some authors use terms psychopathy and sociopathy as synonyms; some refer to sociopathy as subtype of psychopathy influenced by social forces and early experience (Radulovic, 2005a).

Contemporary understanding of psychopathy, defined by its link with crime is reflected on the description of psychopathy in the latest American and International psychiatric classifications of mental disorders. In American classification DSM-IV (APA,1994) the definition of "antisocial personality disorder" (term intend to describe behaviour aspects of psychopathy), basically points to antisocial orientation of such individuals and the danger that they represent to the society.

Criteria, used to diagnose psychopathy as Antisocial personality disorder (301.7), are operational through open, behavioural demonstrations of deviant and criminal conduct in adults (from the age of $18^{\text {th }}$ ). But, the connection to behaviour- 
al problems surely existed during juvenile. That is why a diagnostic request for recording conduct disorder in individuals under the age of $15^{\text {th }}$, categorized as antisocial personality disorder has been made. In order to establish a diagnosis in adult age, three out of seven listed characteristics need to be manifest: 1 . failure to confirm to social norms with respect to lawful behavior as indicated by repeated performing acts that are grounds for arrest; 2.deceitfulness as indicated by repeated lying, use of aliases, or cunning others for personal profit or pleasure; 3.impulsivity or failure to plan ahead; 4.irritability or aggressiveness, as indicated by repeated physical fights or assaults; 5.reckless disregard for safety of self or others; 6.consistent irresponsibility as indicated by repeated failure to sustain consistent work behavior or honor financial obligations; 7.lack of remorse as indicated by being indifferent to or rationalizing having hurt, mistreated, or stolen from another.

This diagnosis excludes the occurrence of antisocial behavior during the course of mental illness, such as Schizophrenia or Manic Episode.

In International classification ICD-10 (WHO,1992) psychopathy is defined as "dissocial personality disorder" (F60.2) usually coming to attention because of a gross disparity between behavior and the prevailing social norms, and characterized by at least 3 of the following: (a) callous unconcern for the feelings of others; (b) gross and persistent attitude of irresponsibility and disregard for social norms, rules and obligations; (c) incapacity to maintain enduring relationships, though having no difficulty in establishing them; (d) very low tolerance to frustration and a low threshold for discharge of aggression, including violence; (e) incapacity to experience guilt and to profit from experience, particularly punishment; (f) marked proneness to blame others, or to offer plausible rationalizations, for the behavior that has brought the patient into conflict with society. There may also be persistent irritability as an associated feature. Conduct disorder during childhood and adolescence, though not invariably present, may further support the diagnosis.

Unlike the psychiatric description, which remains on the level of antisocial behaviour, crime psychologists insist on stricter and less inclusive definition of psychopathy, determined primarily by characteristics of an individual which is the foundation of such behaviour and which becomes evident in early years. They warn that a psychopath, by its personality, is naturally inclined to committing criminal offence, so, according to Robert Hare (1993,p.83) "crime is a logical outcome of psychopathy." He defines psychopathy as a cluster of mutually linked affective, interpersonal and behavioural features with two factors as its base. The first, aggressive narcissism is characterized by egotism, insensibility and lack of remorse. It is correlated with narcissistic and histrionic disorders of personality, low level of anxiety, empathy, pronounced Machiavellianism and narcissism. The sec- 
ond factor is antisocial life style characterized by irresponsible and impulsive behaviour, need for excitement, unconventional and antisocial conduct. This factor is most prominently correlated with criminal conduct and undesirable socio-emotional milieu during formative period and the diagnosis of "behavioural disorder" and "antisocial personality disorder" (Harpur, at al.1989).

Over the past forty years, a view has been present in the literature whereby sociopsychobiology does not consider psychopathy a psychiatric category, not even a psychological disorder, but rather a subspecies of men developed through evolution which, based on strategy of cheating, lying and manipulation, even bloodthirsty violence, successfully acquires resources and all that it desires (Mealey,1995). Hare (1993) himself describes psychopaths as social predators who use charm, intimidation and violence to control others and to satisfy personal egocentric, deviant needs. Totally unscrupulous, lacking empathy and remorse, "they calmly take what they want and do as they please“ (Hare,1993, p.45). Because of their promiscuous and producing large number of children, without investing in their development, beside social pathway developed psychopaths, it could be expected the number of psychopath with genetic predispositions might significantly increase.

The author of this paper emphasis importance of psychological, not psychiatric diagnostics of psychopathy, because it has been empirically determined that a psychopathic disorder, being on the border area between mental health and mental illness, is primarily psychological by nature, since the same traits, evident in normal people, are also found in psychopaths but are of a different degree of expression (intensity). These also have a different structure which naturally gives manifest behaviour an emphasized antisocial quality (Radulović, 2006a: p.74). According to this conception, psychopathy is defined a relatively permanent state of psychological personality structure which is characterized by: (a) unique compose of personality traits dominated by aggressiveness, (b) antisocial, egocentric and hedonistic value orientation with a marked lack of moral code and presence of malevolent intentions; and (c) behavioural demonstration of conduct disorder in which committing crime stands out ( ibidem p.74).

The listed aspects of psychopathic profile such as distinctively heightened aggressiveness, lack of moral (or the creation of the so called "inverse moral" which operates as if mirrored and according to the principle "the worse the better") and disturbed behaviour are already evident in juvenile (Farrington et al, 1986, Moffitt, 1993, Radulovic, 2006b).

Regardless of the definition of psychopathy, one of its main features is persistent and varied, deviant and antisocial behaviour which starts at an early age (Hare, 1993, Hart\& Hare,1997, Robins,1978,1966, Robins at al. 1991). Regrettably, pro- 
fessional circles rarely mention that delinquency at a children's age represents one of the serious early symptoms of psychopathy (Radulovic, 2005b). Instead, early age when a minor commits his/her first criminal offence is regularly taken for what it is; a valid, reliable predictor of future delinquent behaviour, unrelated to psychopathy (Radulovic, 2006a). This is how a person's psychopathic personality, which persistently produces criminal activities and deviant behaviour at later stages, remains completely unnoticed.

\section{Why is psychopathy the core issue in reduction of crime?}

How serious an issue psychopathy in crime is, we learn from Hans Eysenck (1977: 55) who said that the psychopathy presents "the riddle of delinquency in particularly pure form, and if we could solve this riddle in relation to the psychopathy, we might have a very powerful weapon to use on the problem of delinquency in general”.

It is not surprise that over the past several decades a lot of researches, socio-psychological in particular, has been dedicated to the relation between psychopathy and crime (Cleckey, 1976, Hare, 1996, Meloy, 1992, Blackbourn, 1986). Knowledge so far has been based on the results of such research, undoubtedly proving that psychopathy is a nucleus of crime, and that focusing on strategically solutions in this area is necessary, bearing in mind that in terms of criminal law, psychopathy is still an enigma( Eysenck, 1998, Bartol, 2002, Lykken, 1995, Radulovic, 2006a).

Evidence supporting this statement is plentiful and here only some of relevant indicators of its importance for reduction of crime will be presented.

The role of psychopathy is crime is analyzed concerning all relevant criminological parameters as: intensity of crime, duration of criminal career, incidence in penal institution, criminal versatile, violent offences and recidivism. Beside that, next important issues are analyzed: early juvenile delinquency as indicator of psychopathy, deficit of aversive learning of psychopath offenders, unsatisfactory effects of resocialization, failure of specialized treatments and difficulties of identification of psychopaths in criminal and noncriminal population and at last, psychological characteristics of psychopaths relevant for crime.

\section{Relevant criminological indicators of substantial role of psychopathy in crime}

\subsection{Intensity of crime}

Majority of criminal offences is committed by psychopaths, even when we find them in relatively low percent in some samples (Farrington et al,1986, Hare, 1996 ) . They commit all types of offences on a much larger scale, including the 
acts which do not constitute physical violence (fraud, forgery, crimes against the property, and economic crime) and acts of violence in particular (Hart, Hare, 1997, Radulovic,2006a). Many reports indicate that psychopaths are convicted two to three times as often for all criminal offences than non-psychopaths and even four times as often for acts of criminal violence ( Hare, McPherson, 1984). That is the best proof of how intense their criminal behaviour is, although their real, illegal activities are most probably even more intense, since many of their deeds remain undetected. It is deemed that they are responsible for the bulk of the dark figures of crime ( Beck,1993).

\subsection{Criminal career}

Criminal career of a psychopathic delinquent is much longer than that of a non-psychopathic criminals, because the former begins their career very early in life, most likely before $15^{\text {th }}$, usually around the age of $10^{\text {th }}$, and such a career lasts throughout their lives.

That goes for all types of criminal acts, although in later years (after forty) arrests of psychopaths involved in concealment of crime are less frequent (and are reduced to capturing of non-psychopaths), solely for violent crimes, and not for crime against the property (Hare, 1993). Because their criminal activities are permanent and persistent, criminal-law system, in fact does not cease to deal with them for, as long as they live. At the same time, the society is inflicted enormous material and social damage. Nevertheless they know very well that they are doing unlawfully (in opposite to mental ill psychosis who are unable to understand rules and consequences), psychopaths show a stunning lack of concern for the devastation effects their actions have on others, they do not care for the pain and destruction they cause; and with completely lack of guilty they continuous to be ruler broker.

\subsection{Incidence in penal institutions}

The higher the incidence of psychopathy we could find in the higher the level of security of a penal institution. While generally psychopaths' representation within the criminal population is about $20 \%$ (although they are accounted for the majority of criminal activities) research shows that most of about $70 \%$ of adult offenders that we meet in penal institutions with closed and very closed regimes, have psychopathic personality(Radulovic,2006a). If we use mentioned criteria for antisocial personality disorder the percent will be much higher in that setting, nearly $90 \%$. As minors, criminal psychopaths all went, unsuccessfully, through all types of sanc- 
tioning of juvenile delinquency, as determined by the law, starting with educational measures of individual supervision, and including referral to correction institutions, institutions for state supervised education, or specialized institution for treatment and rehabilitation, and punishment of juvenile confinement.

\subsection{Criminal versatile}

Criminal activities of psychopaths, unlike those of non-psychopathic criminals, are incomparably diverse (Hart, Hare, 1997). Psychopaths do not specialized in a particular type of crime but they commit all kinds of criminal offences and also, without fail acts of violence (85-90\% of all cases). Even though they may prefer a particular types of crime, for example serial killing, their criminal careers show their involvement in all types of criminal activities, whether or not officially registered (Radulovic,2006a). Tenacity, flexibility and a high degree of criminal potential of psychopaths is reflected in the very fact that their criminal activities are highly extensive and actually include all forms of crime, classic as well as new ones. These encompass minor theft, traffic violations, deceit, forgery, false introduction, family violence, kidnapping, extortion, corruption, car theft, burglary, banditry, robbery, murder, white slavery, trafficking in human organs, computer fraud, narcotics trafficking, various types of sexual offences, marketing of products detrimental to human health, terrorism, espionage, homicide and luring to suicide within sects, business crime, making and spreading criminal associations globally, numerous varieties of criminal activities of organized crime, etc. Psychopaths are very proud of their enormous criminal versatility (Hare1993), just as for the enormous dark number of crime they are able to generate ( Radulovic, 2006a, Hare, 1996).

\subsection{Violent offences}

In a dynamic and very versatile criminal career of a psychopath, cases of severe acts of violence are often found (Blackburn, 1998, 1986, Momirović, Popovic, 2002, Radulovic, 2004, 2006a). Psychopaths are generally violent both within their families and at work, and especially towards unfamiliar individuals but also to various officials. Largest numbers of extremely destructive criminals, such as serial killers, are recruited from the ranks of psychopaths (Radulović, 2004).

Particularly common and dangerous form of psychopathic violence, and continually recurring, is sexual violence, whose victims are youngsters as well as adults (Quinsey et al., 1995, Harris et al. 1991, Hare, McPherson, 1984). A psychopathic offender with a diagnosis of being a sexual sadist is deemed the most dangerous 
type of delinquent within a criminal population, in general. They are the hardest recidivists and their sexual offenses start very early, as minors (Hart, Hare, 1997). Apart from physical forms of violent behaviour, psychopaths are also prone to psychological violence, too, which sadly is not legislatively sanctioned although it weighs differently compared to psychological violence of non-psychopaths, because it tends to directly and unexpectedly change into a severe form of physical violent behaviour (Radulović, 2004).

\subsection{Criminal recidivism}

Psychopathy occupies the key place in crime due to extremely high incidences of recidivism of psychopaths, so one can ask whether a serious criminal recurrence can happen outside psychopathy (Cornell at al., 1996, Momirović, Popovic, 2002). Psychopaths are undoubtedly the largest category of recidivists (over 70\%) (Radulovic, 2007).

The rate of general recidivism of psychopaths is three times higher than general recidivism of non-psychopaths, whereas the rate of violent recidivism is four times higher (Hemphill, at al. 1998). This being one of the most significant indicators of their chronic criminal behaviour (Skilling et al., 2002). With risk factors of criminal recurrence all taken to one side, and psychopathy on to the other, the psychopathy risk level surpasses by far all other factors together, regardless of the type of crime (Radulovic, 2007, Skilling et al., 2002, Momirovic et al. 1996).

Recidivism of psychopathic juvenile delinquents is one of the surest signs that they will develop into most dangerous, hardest, most ruthless and unrelenting criminals who take crime for a way of living (Radulovic, 2005b, 2007, Momirović, Hošek, 1997).

\section{Early juvenile delinquency as indicator of psychopathy}

Juvenile delinquency of early psychopaths is a problem which many countries, including the well developed ones, are faced with. Some authors, among which are Lykken (1995), Reid (1998) Hare (1993) and others talk about epidemics of psychopathic delinquency. In the Untied States one fifth of the gravest criminal offences are committed by young offenders, mostly psychopaths. The rate of rise in juvenile delinquency, with psychopathy being a large part of it, has been, for the past fifty years, 250\% (Reid, 1998, Bureau of Justice Statistics, 1998). Juvenile psychopathic delinquents differ from juvenile non-psychopathic delinquents in their criminological characteristics, which can be indispensable in their early detection within delinquent population. As well as starting early, young delinquents com- 
mit all types of criminal acts as minors, with acts of violence being at the top (whereas non-psychopaths are more likely to commit crimes against the property); participating in new forms of crime but also developing them.

Youngest recidivists, leaders of juvenile gangs, destructive vandals, delinquents who commit the most serious acts of violence impersonally, as if doing them was their job, while sending innocent victims (usually unknown individual) messages "nothing personal", come from their ranks. Criminal behaviour of juvenile delinquents is persistent, while crime, deviations, addiction disorders, and premature sexual activities represent regular occurrences. In contrast, juvenile non-psychopathic delinquency is often of transient character and is usually situational or linked to adolescent crisis (Radulovic, 2005b). Differences between juvenile psychopathic and non-psychopathic delinquents are particularly prominent in acts of violence. Violence committed by juvenile psychopaths is callous, cold-blooded, like a business, uncomplicated, and unstoppable. It is carried out without inhibitions, feeling of guilt, empathy and fear, and with a huge potential for dehumanization of victims, interspersed with brutality and sadism. It is generally planned, calculated, and instrumental (Cornell at al., 1996), oriented to a particular goal such as money, sensual pleasure, status, domination, control, or is motivated by revenge or desire to punish the victim. This often happens when the person is a state of intoxication; sometimes it is connected to person's impulsive nature or is motivated by an abnormal need for excitement or risk, or is done simply "for the fun". In contrast, juvenile non-psychopathic violence is reactive and happens in states of heightened emotional tension, rage, anger; as a reaction to an event or a misjudged situation, in which victims are often familiar and close people. Research shows that various types of juvenile psychopaths contribute to the worrying rise of juvenile delinquency. Apart from the so called "frustrated" juvenile psychopaths (brought up in an inadequate, cold, hostile or pathogen family environment) we find among delinquents more and more of the so called "spoilt juvenile psychopaths" who come from affluent families in which they were overprotected and whose parents were overly permissive. Lykken $(1995,1998)$ determined that, along with important, relatively unchanging presence of the so called "genotype" psychopathic crime, generated by the temperament of a predisposed adolescent psychopath who is free of fear and with a weak inhibition system, the world has been overwhelmed by delinquency of the so called "phenotype" juvenile psychopaths (also called sociopaths) whose psychopathic profile is the result of negative socialization (the break-up of families being the main cause). Beside all similarity to genotype psychopathy (egotism, aggressiveness, lack of feeling of guilt etc), phenotype psychopathy also differs from it in one aspect - there is no lack of anxiety. On the con- 
trary, anxiety is quiet evident here. According to Lykken (1998) delinquency of this, most numerous categories of socially formed psychopaths can be reduced by a serious, systemic approach by the society which is focused on prevention and particularly to the improvement of social and educational skills of parents. Lykken also believes that, even children with genotype disposition towards crime, helped by skilled parenting, can be redirected into a socially desirable direction. In his opinion, even the deep-rooted psychopathic features such as the lack of fear, heightened aggressiveness and need for excitement, which result in delinquency, can be adequately channelled into sociable acceptable forms of behaviour but only if backed by sound abilities of parents.

With juvenile psychopathic delinquency on the rise, what is also apparent is psychopathic bend of the system of values which results in favouring parasitism, egotism, Machiavellianism, hedonism, emotional unresponsiveness and blatant forcing of deviant forms of behaviour into becoming conventional, socially acceptable (Radulović, Jugović, 2011).

\section{Deficit of aversive learning of psychopath offenders}

Long criminal career starting from juvenile period and high rate of criminal reoffences convincingly proves that usually punitive reactions to criminal psychopaths do not produce results; so defining new specific strategy for psychopathic offenders has become a necessity. Failure to apply punishment is expected, with this category of offenders, bearing in mind that it has been experimentally proved that psychopaths are less receptive to punishment than non-psychopaths (Lykken, 1957, Momirović i dr, 1974, 1979, Radulovic 2008b). With some definitions of psychopathy, difficulties of aversive learning, noticeable from early childhood, is taken as one of its defining characteristics (Radulovic, 2008c). Pointing out to the inefficacy of punitive system, Cleckey (1976) suggested that punishing psychopaths is the same as trying to teach mathematics to an imbecile. One of the better known psychological explanations of crime, based on psychopathy and known as "the theory of aversive learning deficit", explains delinquent behaviour of psychopaths as poor learning of passive avoidance that is weak aversive conditioning (Radulovic, 2008b).

\section{Unsatisfactory effects of resocialization}

High incidence of recidivism clearly indicates that so far the methods of working with psychopathic criminals which rest on principles of resocialization, have been an absolute failure. So we can agree with Hare (1993: 219) saying that "crim- 
inal justice system spends billions of dollars every year in a vain attempt to rehabilitate or resocialize psychopaths”. We must not ignoring the fact that, nevertheless psychopaths could have good manner and be charming, they, in fact, never have been socialized, so how could we expect that they could be re-socialized (Hare, 1993, Radulovic, 2008c). We can also agree with the supporters of the psychological approach saying that, thanks to our naive aspiration to humanize psychopaths, we put the entire society in danger because they, psychopaths, like manipulative social predators, transform us into their easy prey (Mealey, 1995, Reid, 1998). Physically aggressive psychopaths, however, do not appear violent at first glance, but rather leave an impression of kind, socialized individuals, well mannered, friendly towards people (Cleckey, 1976). But their deeds show them in a completely different light and clearly suggest that the process of socialization has basically never been accomplished (Radulović, 2004). That is why prevention is the only valid alternative (Radulovic, 2006a: 542).

\section{Failure of specialized treatments}

Failure of almost all applicable even specialized treatment programmes for psychopaths so far, including psychotherapy, further supports the issue of the need for quite different method of treatment of criminal psychopaths. Psychopaths are totally resistant to treatment because they are perfectly content with themselves and do not possess a genuine desire to change, not even when making declarative promises (Radulovic, 2012). Neither do they have an emotional potential for bonding and transfer that is essential for therapy.

Some forms of psychotherapy (such as psychodynamics and nondirective client oriented therapy) fail not only to produce satisfactory results, but are contraindicated because psychopaths learn from them how to manipulate people, even better; so that recidivism of psychopaths is even higher after application of such therapies (Rice, at al.,1992, Radulovic,2007). Somewhat more favorable results, but limited and short-lived, come from behavioural approaches which are based on the leaning theory, but their effects are quickly lost as well (Radulovic, 2012).

\section{Difficulties of identification of psychopaths in criminal population}

Identification of psychopaths among adult criminals is the most difficult diagnostic problems of forensic work. Psychopaths are difficult to identify even when they commit gravest criminal acts, such as serial killing. It is exceptionally hard to do so in their adult years because their mask of health and non-criminality is 
extraordinary; and co-morbidity with addiction diseases (van Limbeck idr, 1992) very discernible which is why their criminal acts are attributed mostly to alcoholism, drug influence and the like, and thus the psychopathic type of personality remains completely undetected (Cleckey, 1976, Blackburn, 1985, Hart, Hare, 1997, Cantwell, 1980). At first glance psychopaths seem ordinary or even social well integrated. Besides, they appear "healthier and more stable" than normal people (Hare, 1993). They do not expose fear when most people do, externalize responsibility, convincingly rationalize their behaviour, freely speak their mind, appear complacent, non-aggressive, and polite (Bartol, 2002). Without hesitating, they seek new opportunities which they regularly obtain from various officials, whom they meet, because they make an impression of non-criminals and confident individuals. Hare (1993) organized workshops for forensic experts and authorities on jurisdiction and implementation, presenting to participants video shots of interviews conducted during prison examinations of serious, violent delinquents. The experts were not told who the people in the video shots were, but were expected to conclude that, based on authentically recorded statements and behaviour of the interviewees. Majority of delinquents made positive impression on the experts who gave them marks such as "very impressive", "honest and righteous", "possesses good interpersonal skills", "intelligent and articulated" and the like. The knowledge about criminal history and arrests of the subjects from the video shots, which they acquired later, came as a great surprise to them. It also served as a lesson about how aggressive psychopaths present themselves in a positive light, thus making it very difficult to ascertain, based solely on their appearance and stories, that they are in fact hardened criminal. That is why it is essential to detect this personality profile as early as possible.

Identification of psychopaths within a delinquent population is made more difficult also because of a detrimental tendency to wrongly equate or mix psychopathy with a severe mental disorder - psychosis, which is spread not only among public but also among experts outside psychological and psychiatric fields (lawyers, pedagogues, etc). It must be absolutely clear that with psychopathy it is not a question of a pathogen process, but a relatively permanent state that is a psychological disorder of a person's structure that is evident in early developmental phases. Because of configuration of their personality traits, psychopaths are placed, rather early in life, between the mentally sane and the mentally ill, staying permanently prone to social deviations and crime, despite of the persons' being aware of their own actions. This prejudice is permanently maintained not merely because of ignorance, but also because normal people find it difficult to perceive the existence of persons who know exactly what they are doing, even when they are perpetrating the cru- 
ellest of deeds: ferocious murders, rape, felony, which they perform repeatedly, unstoppably and lacking emotion, as is the case with psychopaths (Radulovic,2006a).

\section{Psychological characteristics of psychopaths relevant for crime}

Numerous psychological studies found out psychopaths patterns of personality traits is prone to crime (Lykken, 1995, Blackburn, 1985, 1986, Eysenck, 1977, Radulovic, 2008a). They also confirm the hypotheses that psychopaths offenders are different from others offenders just in psychological traits that are relevant for crime. Psychopathic offenders exhibit a distinct set of personality traits, primary character deficits that predispose them toward long term criminality (Hare et al. 1992, Momirovic, Popovic, 2002, Cleckey, 1976, Bartol, 2002). Affective life of psychopaths is on low level, marked with chronic anger and explosiveness, without deeply felt emotions for others, without guilt or remorse. Their feelings are pre-socialized with domination of boredom, excitement, range, envy etc. Emotions related to others are completely absent as: empathy, sympathy, gratitude, guilty, etc. (Goleman, 1997). Criminal psychopaths are self-centred, grandiose, pathological narcissistic, identified with predatory objects (Meloy,1992). Their relationships are defined by dominance, not affection, just as their violent crime is primary predatory, rather than affective violence, motivated often by hedonistic calculation and higher level of aggression.

Large number of studies directly supported Eysenck`s thesis that psychoticism as a measure of psychopathy very significantly distinguish, not only between criminals and non-criminals, but also among chronic criminals and others who are not psychological prone to crime (Rutter, Rutter, 1993). Traits correlation together to define psychoticism are attributed as: aggressive, cold, egocentric, impersonal, impulsive, antisocial, unempathic, creative, tough-minded (Eysenck, Zuckerman, 1976, Eysenck, 1998).

In the research of Radulovic (2008a) conducted on the sample of 322 serious offenders (with subsample of 209 psychopaths), it was found out that the psychopath offenders were more aggressive, dissociate, hysteric and amoral, with lower level of perceptive and verbal abilities, than non-psychopath offenders. That personality pattern makes them very dangerous and inclined to chronic predators violent crime (Radulovic, 2008a).

\section{Conclusion}

Judging from the analysis of the researches results in the field of psychology of crime, psychopath offenders are the key target category to reduction of crime; specially part that is most worrying, and is the hardest and so far unsolvable, and 
the one which many countries around the world are faced with, in their unsuccessful endeavours to combat it, despite their developed economies, socio-political systems and enormous funds and efforts invested in attempts to prevent its spreading.

Contribution of psychopathy to crime is substantial concerning all relevant criminological parameters as: the extent of committed crime, early juvenile delinquency, durations of criminal career, criminal versatile, and commitment of violence, especially cold blooded, calculated, instrumental violence offences, severity of criminal act, untreatability and very high rate of recidivism. Obviously, psychopathy is not merely an isolated category of crime, but represents its nucleus (Eycenck, 1977, 1998, Radulovic, 2006: 523).

That is why any kind of work aimed at reduction and prevention of crime is destined to have modest results for as long as the essential role of psychopathy in crime is overlooked; together with the fact that psychopathic offenders are not essentially, psychiatric phenomena (Radulovic, 2008c).

Psychopathy can be best understood in the social context, just from its relation to crime. It is a psychological phenomena which, being a deviation of normality that lacks the quality of mental illness has attributes of a relatively permanent psychological profile which contain personality traits that are interpersonally malevolent (high level of aggressiveness, amoral, hysteria etc.). Constellation of such psychological traits presents serious and dangerous psychological potential, predisposed to crime (Radulovic, 2006a).

Among others, socio-cultural factors play important role in etiology of these malevolent personality traits (ibidem: 236). That is why socio-psychology of psychopathy, undoubtedly, deserves proper attention, so that efforts of reduction of crime and preventive efforts would not end like the attempts aimed at resocialization of psychopaths did - a total failure.

Different strategy approach for solving problem of criminal psychopaths as social predators is needed, based on socio -psychological, instead of clinical researches (ibidem: 528).

In that approach we have to bear in mind that psychopaths are not only in neither jails, nor are they on society margins (Radulovic, 2008c). Authors as Cleckey (1976) and Hare (1993) warned us that "our failure to acknowledge the psychopaths are among us, triggered a social crisis” (ibidem: p.163). Nowadays signs of social threatening, predators way of living are everywhere, promoted and intruded as social acceptable model. Psychopathic life style became more widespread, making social crisis and crime much worse, so we could agree with Hare's thesis of living in the "camouflage of society" (ibidem: 175). 


\section{REFERENCES}

American Psychiatric Association (1994). Diagnostic and statistic manual of mental disorders. Washington. DC: American psychiatric association.

American Psychiatric Association (1952). Diagnostic and statistic al manual of mental disorders. Washington, DC: APA American psychiatric association.

Bartol, C. (2002). Criminal behaviour: A psychosocial Approach. New Jersey: Prentice Hall.

Beck, A. et al. (1993). Survey of state prison inmates. Washington, DC: Bureau of Justice Statistics. Blackburn, R. (1975). An Empirical Classification of Psychopathic Personality. British Journal of Psychiatry 127: 456-460.

Blackburn, R. (1985). Identifying the Psychopath: The Relation of Cleckley's Criteria to the Interpersonal Domain. Personality and Individual difference 6: 375-386.

Blackburn, R. (1998). Psychopathy and the Contribution of Personality to Violence. In: T. Millon, E. Simones, M. Briket-Smith, R. Davis (eds), Psychopathy: antisocial, criminal and violent behaviour, New York \& London: Guilford Press, pp. 50- 69.

Blackburn, R. (1986). Patterns of personality deviation among violent offenders: Replication and extension of empirical taxonomy. British Journal of Criminology 26: 254-269.

Bureau of Justice Statistics (1998). Criminal victimization trends in United Stated: 1973-92. Annapols, MD.

Cleckey, H. (1976). The mask of sanity. St. Louis Mosby.

Cornell, D., Warrent, J., Hawk, G., Stafford, E., Ornam, G. and Pine, D. (1996). Psychopaty in instrumental and reactive violent offenders. Journal of Consulting and Clinical Psychology 64: 783-90.

Cantwell, D.P. (1993). Drugs and medical intervention. In: B. Dolan, J. Coid (Eds), Psychopathic and antisocial personality disorders: Treatment and research issues. London: Gaskell.

Eysenck, H. J. (1977). Crime and Personality. London: Routledge \& Kegan Paul.

Eysenck, H. J., Zuckerman, M. (1976). Psychoticism. London: Hodder, Stoughton.

Eysenck, H. J. (1998). Personality and crime. In: T., Millon, E. Simonsen, M. Briket-Smith, R. Davis, Psychopathy: antisocial, criminal and violent behaviour, New York \& London: Guilford Press, pp. 40-50.

Farrington, D.P., Ohlin, L.I., Wilson, J.Q. (1986). Understanding and controlling crime: Toward a new research strategy. New York: Springer-Verlang.

Goleman, D. (1997). Emocionalna inteligencija. Beograd: Geopolitika.

Hare, R.D. (1970). Psychopath, Theory and research. New York: Wiley.

Hare, R.D. (1993). Without conscious: The disturbing world of the psychopaths among us. New York: Pocet books.

Hare, R.D. (1996). Psychopathy: A clinical construct whose time has come. Criminal Justice and Behaviour 23: 25-54.

Hare, R.D., Forth, A.E., and Strachan, K.E. (1992). Psychopathy and crime across life span. In: Peters, R.D., McMahon, R.J., Qinsey, V.L. (eds.), Aggression and violence throughout the life span, Newbury Park, CA: Sage. 
Hart, S. D. \& Hare R.D. (1997), Psychopathy: Assessment and association with criminal conduct. In: Stoff, D. M., Brieling, J., and Maser, J. (Eds), Handbook of Antisocial Behaviour, New York: Wiley, pp. 22-35.

Hare, R.D. \& McPherson, L.M. (1984). Violent and agressive behavior in criminal psychopaths. International Journal of abnormal psychology 100: 392-339.

Harpur, T.J., Hare, R.D, (1989). A two factor conceptualization of psychopathy: Construct validity and implications for assessment. Psychological Assessment 1: 6-17.

Harris, G.T., Rice, M.E., Cormer, C.A. (1991). Psychopathy and Violent Recidivism. Law and human behavior 15: 625 -637.

Hemphill, J.F., Hare, R.D., Wong, S. (1998). Psychopathy and recidivism: A review. Legal and Criminological Psychology 3: 139-170.

Lykken, D. (1957). A study of anxiety in sociopathic personality. Journal of Abnormal and Social Psychology 55: 6-10.

Lykken, D. (1995). The antisocial personalities. Hillsdale, NJ: Erlbaum.

Lykken, D. (1998). The case of parental licensure. In: T., Millon, E. Simonsen, M. Briket-Smith, R. Davis (eds), Psychopathy: antisocial, criminal and violent behaviour, New York \& London: Guilford Press, pp. 122-144.

Mealey, L. (1995). The sociobiology of sociopathy: An integrated evolutionary model. Behavioral and Brain Sciences 18: 523-599.

Meloy, J.R. (1992). The Psychopathic Mind: Origin, Dynamics and Treatment. Northvale, NJ: Jason.

Moffitt, T.E. (1993). Life-course-persistence and adolescence - limited antisocial behavior: A developement taxonomy. Psychological review 100: 674-701.

Momirović K., Popović, D. (2002). Psihopatija i kriminal. Leposavić: Univerzitet u Prištini, Centar za multidisciplinarna istraživanja Fakulteta za fizičku kulturu.

Momirović, K., Hošek, A. ( 1997). Osobine ličnosti maloletnih delinkvenata. Časopis za kliničku psihologiju i socijalnu patologiju 4 (1-2): 28-66.

Momirović, K., Hošek, A., Radovanović, D., Radulović, D. (1996). Osobine ličnosti recidivista određene pod nelinearnim kanoničkim modelom. U: Radovanović, D., Psihologija kriminala 3: $13-24$.

Momirović, K., Davidović, D. i dr. (1974). Efikasnost krivičnih sankcija prema maloletnicima. Istraživački izveštaj, Beograd: Institut za kriminološka i sociološka istraživanja.

Momirović, K., Viskić-Štalec, M. i Mejovšek, M. (1979). Relacije kognitivnih i konativnih karakteristika maloletnih delinkvenata i efikasnost resocijalizacije nakon penalnog tretmana. Defektologija (Zagreb) 10: 155-174.

Quinsey, V.L., Race, M.E., and Harris, G.T. (1995). Actuarial prediction of sexual recidivism. Journal of Interpersonal Violence 10: 85-105.

Radulović, D. (2004). Teški oblici kriminala psihopata. U: D. Radovanović (ur.), Teški oblici kriminala, Beograd: Institut za kriminološka i sociološka istraživanja,Viša škola unutrašnjih poslova, str. 387-413.

Radulović, D. (2005a). Razvoj shvatanja o psihopatskom poremećaju ličnosti od značaja za psihologiju kriminala. Zbonik Instituta za kriminološka i sociološka istraživanja XXIV (1-2): 305-345. 
Radulović, D. (2005b). Rana psihopatija i krivične sankcije. U: D. Radovanović: Kazneno zakonodavstvo: progresivna ili regresivna rešenja, Beograd: Institut za kriminološka i sociološka istraživanja, Viša škola unutrašnjih poslova, str. 459-475.

Radulović, D. (2006a). Psihologija kriminala - psihopatija i prestupništvo. Beograd: Fakultet za specijalnu edukaciju i rehabilitaciju, Institut za kriminološka i sociološka istraživanja.

Radulović, D. (2006b). Savremene koncepcije moralnog razvoja od značaja za prevenciju maloletničke delinkvencije. Zbornik Instituta za kriminološka i sociološka istraživanja XXV (1-2): 728.

Radulović, D. (2007). Ključni problem recidivizma: kriminalni povrat psihopata. Revija za kriminologiju i krivično pravo 45 (3): 135-150.

Radulović, D. (2008a). Differences in Cognitive and Conative Characteristics in Psychopath and Non Psychopath Offendres. Internatonal Journal of Social Health Information Management 1 (1): 1-6.

Radulović, D. (2008b). Lykken-ova psihološka teorija kriminala. Revija za kriminologiju i krivično pravo 46 (3): 85-97.

Radulović, D. (2008c). Ljudi bez krivice. U: B. Ćorić (ur.), Ljudi govore: Čovek između krivice i tuge, Fakultet za specijalnu edukaciju i rehabilitaciju Univerziteta u Beogradu, str. 111-128.

Radulović, D. Jugović, A. (2011). Prete li poremećaji ponašanja da postanu norma? Rezime radova 59. Nučno-stručni skup Psihologa Srbije sa međunarodnim učešćem, 1-4 jun 2011., Društvo psihologa Srbije, str. 110.

Radulović, D. (2012). Zašto se nakon forenzičkog tretmana delinkvenata nekada još više učvrsti njihovo kriminalno ponašanje? Specijalna edukacija i rehabilitacija (Beograd) 11 (2): 349-359.

Reid, W.H. (1998). Antisocial Character and Behavior: Threats and Solutions. In: T. Millon, E. Simonsen, M. Birket-Smith, R. Davis (Eds), Psychopathy (antisocial, criminal and violent behaviour), New York: Guilford Press, pp. 110-121.

Rice, M.E., Harris, H.T., Cormier, C.A. (1992). An evaluation of maximum security therapeutic community for psychopaths and other mentally disordered offenders. Low and human behaviour 16: 399-412.

Robins, L.N., Price, R.K. (1991). Adult disorders predicted by childhood conduct problems: Results from the NIMH Epidemiologic Cathment Area project. Psychiatry 54: 116-132.

Robins, L. (1966). Deviant Children Grown-Up. Baltimore: Williams and Wilkins.

Robins, L. (1978). Sturdy childhood predictors of adult antisocial behaviour: Replications from longitudinal studies. Psychological Medicine 8: 611-622.

Rutter, M., Rutter, M. (1993): Developing minds: Challenge and continuity across the life span. New York: Basic Books.

van Limbeck, J., Wouters, L., Kaplan, C.D., Geerlings, P.J., van Alem, V. (1992). Prevalence of psychopathology in drug-addicted Dutch. Journal of Supstance Abuse Treatment 9: 43-52.

Skilling, T.A., Harris, G.T., Rice, M.E., Quinsey, V.L. (2002). Identifying persistently antisocial offenders using the Hare Psychopathy Checklist and DSM antisocial personality criteria. Psychological Assessment 14: 27-34.

World Health Organization (1992). ICD-10 Classification of mental and behavioural disorders: Clinical Descriptions and diagnostic guidelines. Geneva: Author. 
Данка Радуловић

Сажее̄̄ак

Универзитет у Београду

Факултет за специјалну едукацију

и рехабилитацију

\section{ГЛАВНИ ПРОБЛЕМ КРИМИНАЛА У ДРУШТВУ: ПРЕСТУПНИЦИ ПСИХОПАТЕ}

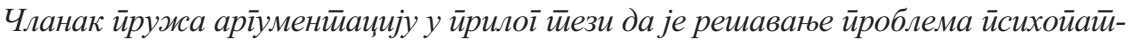

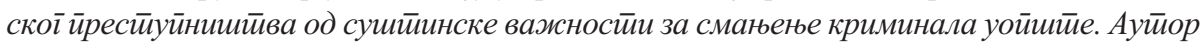

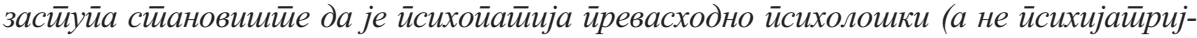
ски) феномен који има значајне криминолошке имйликације. На бази резулйайа емйиријских истираживања анализирани су сви релеванитни индикайори доириноса йсихо-

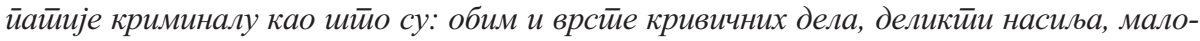
летиничка делинквенција и рецидивизам. Устиановљено је да су већина тиешких кривичних дела, рана делинквенција, дужина киминалне каријере, учестиалосии у извршену кривичних дела, укључујући йамне бројке криминала и рецидивизам, сушииински йовезани са йсихойайијом. Психойайе су укључене у све форме криминала, а иоосебно у криминал насиља. Њихово је насиье инсиируменитално и ирредайорско, а не йсихойайолоико као код душевних болесника, а нарочийо су ойасне сексуалне йсихойайе. Немоїући су за йрейман и слабо им је аверзивно учење, али их је збоі маске некриминоїено-

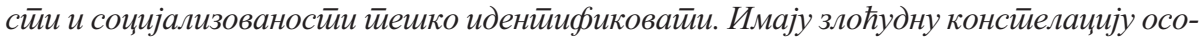

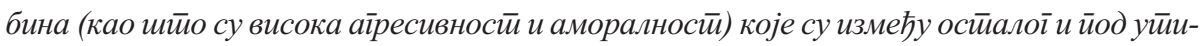

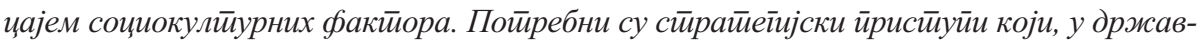
ној реакцији и йревенцији, уз смањење йсихойайскоі криминала обезбеђују сииварање

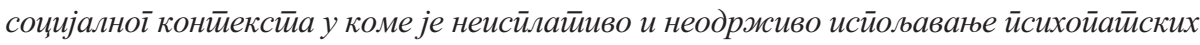

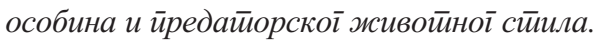

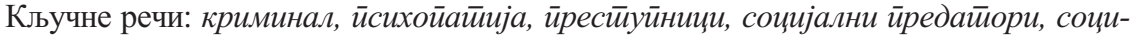
ойсихолоїија, криминолоїија 